\title{
NOTE
}

\section{SEA GRASSES, A NEW UNREPORTED HABITAT FOR THE HETEROBRANCH MOLLUSK Umbraculum umbraculum IN THE CARIBBEAN REGION}

\author{
Erika García-Bonilla ${ }^{1}$, Paula González ${ }^{1}$, Laura Pirateque ${ }^{1}$, JÜrgen Guerrero-Kommritz ${ }^{2}$, \\ Mónica Puyana ${ }^{3}$ and Alberto Acosta ${ }^{1}$ \\ ${ }^{1}$ Grupo de Investigación Unidad de Ecología y Sistemática (UNESIS), Departamento de Biología, \\ Facultad de Ciencias, Pontificia Universidad Javeriana, Carrera 7 № 43-82, Bogotá, Colombia \\ e-mail: ejgb30@gmail.com \\ ${ }^{2}$ Fundación Fundabas, Bogotá, Colombia \\ ${ }^{3}$ Grupo de Investigación Bioprospección y Biotecnología, \\ Departamento de Ciencias Biológicas y Ambientales, Facultad de Ciencias Naturales e Ingeniería, \\ Universidad Jorge Tadeo Lozano, Carrera 4 № 22-61, Bogotá, Colombia
}

\begin{abstract}
Herein, a new habitat for the heterobranch mollusk Umbraculum is described. One specimen was found on a Thalassia testudinum bed at Taganga Bay at $3 \mathrm{~m}$ depth, a buffer area of the Tayrona National Park, Colombian Caribbean. To the best of our knowledge, these mollusks have not been previously reported in this kind of habitat. Seagrasses may provide protection and possibly serve as areas for its reproduction.
\end{abstract}

Key words: Heterobranch, habitat, Thalassia testudinum, Colombian Caribbean.

\section{INTRODUCTION}

Among Caribbean gastropods, heterobranchs are an uncommon sight due to their low local abundances. Except for some local population pulses of aplysiids (sea hares), heterobranchs are largely overlooked as a group (Diaz and Puyana 1994). Umbraculum (Mollusca: Gastropoda: Heterobranchia: Umbraculida: Umbraculidae) has a cosmopolitan distribution in warm tropical and temperate waters (Wägele et al. 2006a).

Umbraculum umbraculum has been given different names at various geographic regions (Sankar et al. 2011). The species was recently reported at the Bay of Biscay, eastern Atlantic Ocean (Arias and Crocetta 2016). The local sea- water temperature generally ranges from $12-13{ }^{\circ} \mathrm{C}$ in winter (January-February) to $21-22{ }^{\circ} \mathrm{C}$ in summer (July-August). However, a generalized sea surface warming (an upward trend of the sea surface temperature series) and intensification in the upwelling intensity during the summer months has been registered off the Santander and Bilbao coast during the last two decades (Bode et al. 2013). This increase in temperature influences significant changes in the local faunal composition (Bode et al. 2013) and may be considered an indication of a tropicalization of the area, a pattern that has also been shown in coral replacement of kelps in southern Japan (Vergés et al. 2014).

Morphologically, U. umbraculum is characterized by its long foot and a flat shell covering its body (Mikkelsen 2002). It has a deep orange color and a mantle covered with pustules. As 
other members of the Order Umbraculida, Umbraculum spp. are specialist predators on a wide array of sponges (Willam 1984; Avila et al. 2018). Heterobranchs are well known for sequestering, transferring and even modifying metabolites from their diet for defensive purposes (Faulkner and Ghiselin 1983; Cimino et al. 2001). These compounds may be released via mucus or concentrated in the mantle dermal formations or other glandular structures (Wägele et al. 2006a). The only metabolites from $U$. umbraculum known to date are two diacylglycerols and a fatty acid ester probably produced by the sponge Geodia cydonium in the Mediterranean where the mollusk was collected (Cimino et al. 1988, 1989). Until now, little is known about the ecology of heterobranchs such as U. umbraculum, even though its presence is recognized in the Caribbean region. Information about habitat preferences, food and reproduction patterns is scarce. This note describes a recent finding of this mollusk on a previously unreported habitat, which may provide shelter during various stages of its life cycle.

\section{Habitat characteristics}

A solitary specimen of the heterobranch mollusk Umbraculum umbraculum was found on March 1, 2018 at a Thalassia testudinum bed at Taganga bay, a buffer area of the Tayrona National Park, Colombian Caribbean ( $11^{\circ} 16^{\prime} 16.1^{\prime \prime} \mathrm{N}$ $74^{\circ} 11^{\prime} 54.1^{\prime \prime} \mathrm{W}$; Figure $\left.1 \mathrm{~A}\right)$ at $3 \mathrm{~m}$ depth. The area is affected by local coastal upwelling from December to March. In these months, seawater temperature may drop to $20-25{ }^{\circ} \mathrm{C}$ (Diaz-Pulido and Garzon-Ferreira 2002; Bayraktarov et al. 2012). The seagrass bed where we found the specimen was located on a muddy sand substrate at the leeward side of the bay (Figure $1 \mathrm{~B}$ ). We carried out some preliminary evaluations to assess the conservation state of this seagrass bed in particular. In an area of $100 \mathrm{~m}^{2}$, we measured parameters such as shoot density, growth rate and overall biomass. We determined that this bed has a rather low density $\left(88\right.$ shoots $\mathrm{m}^{-2}$, each bearing two to five short leaf blades, $15 \mathrm{~cm}$ long, growing from a basal meristem). The calculated growth rate was of $0.8 \mathrm{~cm} \mathrm{day}^{-1}$, yielding an overall biomass of $5.04 \mathrm{~g} \mathrm{~m}^{-2}$ and reaching a productivity of $0.15 \mathrm{~g} \mathrm{~m}^{2}$ day $^{-1}$. These biological features, together with rather intense tourist activity in the area, and ecosystem risk analysis (Bland et al. 2016) allow us to consider that this seagrass bed is in a poor conservation state, and possibly in Critical Risk of collapse according to IUCN categories.

Specific habitat preferences for U. umbraculum have not been well documented to date. The species has been only reported at shallow sandy bottoms in Greece (Wägele et al. 2006b; Sankar et al. 2011). In Colombia, a specimen (Catalog number INV MOL-1595; MAKURIWA-Marine Natural History Museum of INVEMAR; http://siam.invemar.org.co/buscador) was collected on soft bottoms (70 m depth) at Cabo de la Vela (Marcus and Marcus 1967) in the upwelling area of the Guajira $\left(12^{\circ} 12^{\prime} 15.7^{\prime \prime} \mathrm{N}-72^{\circ} 10^{\prime} 59.4^{\prime \prime}\right.$ W) and also seen at Tayrona National Park (Ardila et al. 2007).

To the best of our knowledge, there are no previous reports of $U$. umbraculum thriving in Thalassia testudinum beds. As with other heterobranchs, U. umbraculum might gain protection from predation among the seagrass blades and may also find suitable food sources, once, in our field evaluations, we found several specimens of Agelas spp. and other sponges. Additionally, the animal observed was in reproductive mode since upon collection it released copious amounts of sperm (Figure $1 \mathrm{C}$ and $1 \mathrm{D}$ ), which suggest that U. umbraculum uses the upwelling season (January to March) to migrate to shallow water and reproduce as others mollusks do at Taganga Bay such as Octopus hummelincki (Adam, 1936) and Aplysia dactylomela (Rang, 1828) (Jürgen Guerrero-Kommritz, Pers. Observ.).

Habitat and water quality in Taganga bay have diminished over the last four decades. The bay is 

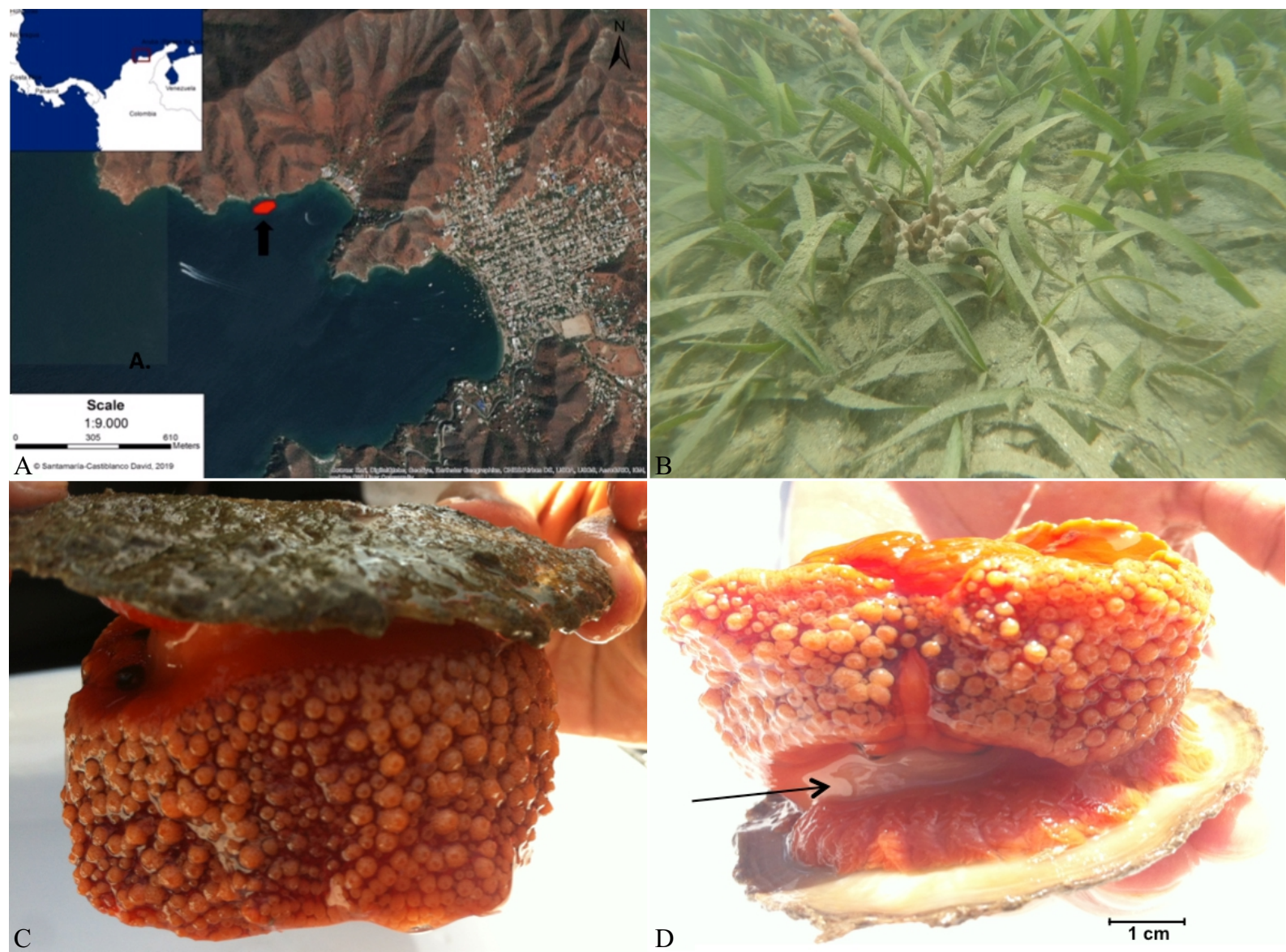

Figure 1. A) Map of the seagrass bed where the specimen of Umbraculum umbraculum was found (red dot) at Taganga Bay, Colombian Caribbean. B) Detail of the seagrass habitat, with profuse growth of sponges that could potentially be a food source for this opisthobranch. Seagrasses could also be an important breeding habitat for this mollusk. C-D) Live specimen of $U$. umbraculum collected; note the sperm released by the individual (arrow).

subject to high sedimentation rates coming directly from local sources (the Manzanares and Gaira rivers as well as seasonal stream flows into Playa Taganga) and indirectly through the Magdalena river plume, particularly after heavy rains. The fact of finding this specimen suggests two possible scenarios: the first one is that seagrasses may be a suitable habitat for this species, where potential predators such as fishes and crabs are significantly diminished due to overfishing. Alternatively, the presence of this mollusk species might represent a threat for other animals such as sponges upon which they prey upon. Overall, we believe that the seagrass bed at Taganga bay may provide food and shelter for many invertebrate species and possibly vertebrates as well, from adjacent rocky shores, reef formations and soft bottoms (Pawlik 1998; Pawlik et al. 2018).

While brief, this report is of great interest to gain some further insights on the distribution and ecology of this uncommon mollusk. It also raises new questions concerning its potential vertical migration, as well as food and habitat preferences. Further research should provide more insights on the life habits of $U$. umbraculum in the Caribbean region. 


\section{ACKNOWLEDGEMENTS}

The authors acknowledge Erika Montoya at INVEMAR for providing biological information of $U$. umbraculum registered in Colombia.

\section{REFERENCES}

Ardila N, BÁez D, VAldés A. 2007. Babosas y liebres de mar (Mollusca: Gastropoda: Opisthobranchia) de Colombia. Biota Colomb. 8: 185-197.

Arias A, CRocetta F. 2016. Umbraculum Umbraculum (Gastropoda: Heterobranchia) spreading northwards: additional evidence to the "tropicalization" of the Bay of Biscay. Cah Biol Mar. 57: 285-286.

Avila C, Nuñez-Pons L, Moles J. 2018. From the tropics to the poles. Chemical defense strategies in sea slugs (Mollusca: Heterobranchia). In: Puglisi M., BeCERro M, editors. Chemical ecology: the ecological impacts of marine natural products. Taylor \& Francis Group. p. 71-163.

Bayraktarov E, Pizarro V, Eidens C, Wilke T, WiLD C. 2012. Upwelling mitigates coral bleaching in the Colombian Caribbean. Proceedings of the 12th International Coral Reef Symposium, Cairns, Australia. p. 9-13.

Bland LM, Keith DA, Miller RM, Murray NJ, RODRÍGUEZ JP. 2016. Directrices para la aplicación de las categorías y criterios de la lista roja de ecosistemas de UICN. Gland: IUCN, Gland, Suiza.

Bode A, Bueno J, Lopez-Urrutia A, Villate F, Uriarte I, Iriarte A, Alvarez-Ossorio M, Miranda A, Casas G, Dos Santos A, et al. 2013. Zooplankton of the Bay of Biscay and Western Iberian Peninsula. In: O'Brien T., Wiebe P., Falkenhaug T, editors. ICES Zoo- plankton Status Report 2010-2011. International Council for the Exploration of the Sea (ICES). p. 132-160.

Cimino G, Ciavatta M, Fontana A, Gavagnin M. 2001. Metabolites of marine opisthobranchs: chemistry and biological activity. In: TRINGALI C, editor. Bioactive compounds from natural sources. London and New York: Taylor \& Francis Group. p. 577-638.

Cimino G, Crispino A, Spinella A, Sodano G. 1988. Two ichthyotoxic diacylglycerols from the opisthobranch mollusc Umbraculum mediterraneum. Tetrahedron Lett. 29: 36133616.

Cimino G, Spinella A, Scopa A, Sodano G. 1989. Umbraculumin-B, an unusual 3-hydroxybutyric acid ester from the opisthobranch mollusc Umbraculum mediterraneum. Tetrahedron Lett. 30: 1147-1148.

Diaz-Pulido G, Garzon-Ferreira J. 2002. Seasonality in algal assemblages on upwellinginfluenced coral reefs in the Colombian Caribbean. Bot Mar. 45: 284-292.

Diaz J, Puyana M. 1994. Moluscos marinos del Caribe Colombiano: un catálogo ilustrado. Bogotá: Fundación Natura. 291 p.

FAulkner D, Ghiselin M. 1983. Chemical defense and evolutionary ecology of dorid nudibranchs and some other opisthobranch gastropods. Mar Ecol Prog Ser. 13: 295-301.

Marcus E, MARcus E. 1967. Opistobranchs from the southwestern Caribbean sea. Bull Mar Sci. 17: 597-628.

MikKelsen P. 2002. Shelled opisthobranchs. In: Southward AJ, Tyler PA, Young CM, FUIMAN LA, editors. Advances in marine biology, molluscan radiation lesser-known branches. Vol. 42. San Diego: Academic Press. p. 67-136.

PAWLIK JR. 1998. Coral reef sponges: do predatory fishes affect their distribution? Limnol Ocean. 43: 1396-1399.

Pawlik JR, Loh TL, McMurray SE. 2018. A review of bottom-up vs. top-down control of sponges on Caribbean fore-reefs: what's old, 
what's new, and future directions. PeerJ. 6: e4343. doi:10.7717/peerj.4343

Sankar R, Raja P, Murugan A. 2011. Occurrence of opisthobranch mollusc Umbraculum umbraculum in Tuticorin coast, Southeast coast of India. Indian J Mar Sci. 40: 487-490.

Vergés A, Steinberg P, Hay M, Poore A, CampBell A, Ballesteros E, Heck K, Boоth D, Coleman M, Feary D, et al. 2014. The tropicalization of temperate marine ecosystems: climate-mediated changes in herbivory and community phase shifts. Proc R Soc B. 281: 20140846. doi:10.1098/rspb.2014.0846

Wägele H, Ballesteros M, Avila C. 2006a. Defensive glandular structures in opistho- branch molluscs-from histology to ecology. Oceanogr Mar Biol. 44: 197-276.

WÄGEle H, VonNemann V, Rudman WB. 2006b. Umbraculum umbraculum (Lightfoot, 1786) (Gastropoda, Opisthobranchia, Tylodinoidea) and the synonymy of $U$. mediterraneum (Lamarck, 1812). Rec West Aust Museum. 69: 6982.

Willam RC. 1984. A review of diets in the Notaspidea (Mollusca: Opisthobranchia). J Malacol Soc Aust. 6: 125-142.

Received: 7 April 2020

Accepted: 20 May 2020 
